\title{
Penerapan Media Animasi Dalam Pembelajaran Sejarah Kebudayaan Islam (Penelitian di SDIT Atikah Musaddad Kabupaten Garut)
}

\author{
Sita Nurlani ${ }^{1}$, Nenden Munawaroh ${ }^{2}$, Ijudin $^{3}$ \\ Universitas Garut \\ nurlanisita@gmail.com, nendenmunawaroh@uniga.ac.id.ijudin.wr1@uniga .ac.id
}

\begin{abstract}
Abstrak
Sejarah Kebudayaan Islam merupakan salah satu mata pelajaran yang lebih menekankan pada aspek cerita. Media animasi salah satu media yang membantu pembelajaran SKI semakin menarik dan inovatif bukan sekedar menyajikan pembelajaran konvensional. Seiring dengan perkembangan era revolusi industry 4.0. Adapun tujuan dalam penelitian ini untuk mengetahui efektifitas hasil belajar Sejarah Kebudayaan Islam dengan menggunakan Media Animasi di kelas IV Sekolah Dasar Islam Terpadu Atikah Musaddad Kabupaten Garut. Jenis penelitian dalam penelitian ini adalah eksperimen semu dengan desain pretest-post test control group design. Populasi dalam penelitian ini adalah siswa pada Sekolah Dasar Islam Terpadu Atikah Musaddad Kabupaten Garut Provinsi Jawa Barat dan sampel yang digunakan dalam penelitian ini masing-masing ada 2 kelas yaitu kelas IV Ilyas dan Kelas IV Sulaiman, dengan teknik sampling purposive sampling. Teknik pengumpulan data yang digunakan ialah tes dan dokumentasi. Teknik analisis Datanya menggunakan uji t dengan prasyarat uji normalitas menggunakan Kolmogorov Smirnov dan uji homogenitas menggunakan Levene's. Dilihat dari rata-rata hasil belajar hasil penelitian ini adalah pembelajaran dengan menggunakan Media Animasi lebih efektif dari pada metode konvensional Dengan demikian penggunaan Media Animasi efektif terhadap hasil belajar SKI di Sekolah Dasar Islam Terpadu Atikah Musaddad.
\end{abstract}

Kata kunci: Media Animasi, sejarah kebudayaan Islam

\section{Pendahuluan}

Memasuki era 4.0 banyak sekali perubahan yang terjadi dalam dimensi kehidupan manusia oleh karena itu perlu upaya-upaya agar tidak tertinggal dari perkembangan IPTEK tersebut. Menurut Agus Setiawan kualitas pembelajaran tidak hanya didukung oleh lembaga pendidikan namun juga sumber daya manusia yang terampil sebagai wujud kualitas pendidikan yang tinggi. Terdapat beberapa unsur di dalam kegiatan belajar mengajar seperti tujuan, metode, bahan pembelajaran, media dan 
penilaian. Menurut Putrawangsa dan Hasanah dalam penelitiannya disimpulkan bahwa penggunaan teknologi dalam pembelajaran pada prinsipnya tidak dapat dipakai untuk pemahaman sebuah konsep dan hasil pemikiran siswa, melainkan hanya dapat membantu meningkatkan pemahaman konseptual dan mengembangkan kemampuan intuisinya. Guru dituntut untuk mampu mendesain atau merancang media pembelajaran sesuai dengan materi pelajaran.

Animasi merupakan satu bentuk tampilan bergambar yang paling menarik, yang berupa simulasi gambar bergerak yang menggambarkan perpindahan atau pergerakan suatu objek. (Sukiyasa \& Sukoco, 2013). Hasil belajar adalah kemampuan-kemampuan yang dimiliki siswa setelah mengalami proses pembelajaran (Appang, Sugiarti, \& Salempa, 2017).

Ada kemungkinan rendahnya nilai kompetensi dan pemahaman siswa disebabkan oleh strategi penyampaian pembelajaran kurang tepat. Dalam hal ini guru mungkin kurang atau tidak memanfaatkan sumber belajar secara optimal. Diantaranya guru dalam menyampaikan pengajaran sering mengabaikan penggunaan media. Pada hakikatnya media berfungsi untuk meningkatkan hasil belajar dan meningkatkan mutu pendidikan siswa.

Mata pelajaran Sejarah Kebudayaan Islam (SKI) merupakan salah satu mata pelajaran Sejarah masa lampau. Dalam sebuah sekolah pastinya ingin anak didik memiliki hasil belajar yang bagus maka dari itu alangkah baiknya guru menerapkan proses pembelajaran yang menyenangkan dan kreatif dalam proses pembelajaran, tidak hanya metode ceramah atau pemberian tugas yang menekankan peran guru lebih dominan dibandingkan siswa selama proses belajar, sehingga siswa cenderung pasif dan jenuh dalam belajar.

Maka dari itu, untuk meningkatkan hasil belajar siswa, saya sebagai peneliti menerapkan media gambar animasi agar siswa merasa terhibur dan senang ketika mempelajari mata pelajaran SKI, media ini sangat efektif karena animasi merupakan proses pembentukan dari berbagai media atau objek yang divariasikan dengan efekefek dan filter, gerakan transisi dan suara-suara.

Berdasarkan hasil penelitian tengah semester tahun 2019/2020 banyak yang masih belum mencapai KKM (kriteria Ketuntasan minimal) nilai KKM yang telah ditentukan 70, dari 47 siswa hanya 23 siswa yang mencapai ketuntasan minimal. Berikut daftar nilai penilaian tengah semester I mata pelajaran SKI kelas IV Ilyas dan kelas IV Sulaiman SDIT Atikah Musaddad Garut.

Berdasarkan hasil observasi awal diketahui bahwa metode pembelajaran yang sering digunakan yaitu ceramah dan pemberian tugas. Melihat kondisi tersebut diharapkan guru menerapkan metode pembelajaran yang lebih variatif yang menuntut keterlibatan siswa secara aktif dalam proses pembelajaran untuk meningkatkan hasil belajar siswa. 


\section{Metode Penelitian}

Penelitian ini menggunakan metode quasi eksperimen design Metode quasi eksperimen juga disebut metode semu.Kelompok Eksperimen penelitian ini adalah siswa kelas IV Ilyas, sedangkan kelompok kontrol adalah siswa kelas IV Sulaiman SDIT Atikah Musaddad Garut. Kelompok eksperimen tersebut merupakan kelas yang menggunakan media gambar animasi (audio visual), sementara kelompok kontrol menggunakan metode ceramah. Kedua kelompok nantinya akan diberi pretest, kemudian diberikan treatment (media gambar animasi), dan terakhir diberikan posttest. Berikut ini merupakan desain penelitian the nonequivalent control group design yang disajikan pada tabel 3.2.1.

Tabel 3.1: Desain Penelitian

\begin{tabular}{|c|c|c|c|}
\hline Kelompok & Pre test & Treatment & Post test \\
\hline Eksperimen & $\mathrm{O}_{1}$ & $\mathrm{X}$ & $\mathrm{O}_{2}$ \\
\hline Kontrol & $\mathrm{O}_{3}$ & & $\mathrm{O}_{4}$ \\
\hline
\end{tabular}

Keterangan

$\mathrm{O} 1 \& \mathrm{O} 3=$ Kedua kelompok tersebut diobservasi dengan pre test untuk mengetahui keadaan awal.

$\mathrm{O} 2$ = Hasil pembelajaran setelah menggunakan media gambar animasi.

$\mathrm{O} 4=$ Hasil pembelajaran yang tidak menggunakan media gambar animasi.

$\mathrm{X}=$ Treatment dengan menggunakan media gambar animasi.

Populasi dalam penelitian ini adalah siswa kelas IV Ilyas dan IV Sulaiman SDIT Atikah Musaddad Al-Wasilah Garut yang berjumlah siswa 44.

Tujuan penelitian ini Diharapkan Mampu membenahi kualitas hasil dan proses pembelajaran melalui media Animasi di kelas IV Ilyas dan kelas IV Sulaiman SDIT Atikah Musaddad Garut menjadi lebih baik. Efektifitas Pembelajaran sejarah kebudayaan Islam dapat dilihat dari meningkatnya hasil belajar siswa. Tindakan dinyatakan efektif, jika terdapat perubahan positif dari sebelumya. Keterbaharuan dalam penelitian ini ialah adanya sebuah majalah elektrik sebagai bacaan siswa yang mencakup isian dari Lembar Kerja Siswa yang dikemas semenarik mungkin dan juga disertai Quiz interaktif dengan iringan musik dan juga penilaian secara langsung sehingga pembelajaran SKI menjadi tepat dan jauh menyenangkan.

\section{Hasil dan Pembahasan}

Sebelum melakukan penelitian di Sekolah Dasar Islam Terpadu Atikah Musaddad Kabupaten Garut Provinsi Jawa Barat, instrumen tes hasil belajar SKI dilakukan uji validitas dan reliabilitas. Hasil validitas butir soal instrumen adalah terdapat 20 butir yang valid dan instrumen yang digunakan reliabel.

Untuk menghitung reliabilitas perangkat soal digunakan rumus KR.2O (Kuder Richardson 20). Berdasarkan uji isntrumen tes yang sudah dilakukan di lapangan sebanyak 25 soal dari 27 siswa kelas $\mathrm{V}$, dapat diperoleh kesimpulannya dari perhitungan yang dilakukan dengan $\mathrm{N}=12$, diperoleh nilai reliabilitas soal yaitu 0,96 yang menunjukkan tingkat reliabilitas instrument sangat tinggi. Hasil uji 
validitas dan reliabilitas instrument dapat dilihat pada tabel di bawah ini:

\section{Tabel 1}

Rekapitulasi Reliabilitas Instrumen

\begin{tabular}{|c|c|c|c|c|}
\hline $\begin{array}{c}\text { Soal valid } \\
\text { digunakan }\end{array}$ & Varian item & Varian total & Reliabilitas & Interpretasi \\
\hline 12 & 0,91 & 7,55 & 0,96 & Sangat tinggi \\
\hline
\end{tabular}

Hasil perhitungan data 2019.

Setelah instrument data penelitian valid dan reliabel, kemudian dilanjutkan uji pemeriksaan data (normalitas dan homogenitas).

\section{Tabel 2}

Uji Normalitas

\begin{tabular}{|c|c|c|c|}
\hline Kelas & $\chi^{2}$ hitung & $\chi^{2}$ tabel & Kesimpulan \\
\hline Eksperimen & 1,00 & 11,34 & Normal \\
\hline Kontrol & 2,79 & 11,34 & Normal \\
\hline
\end{tabular}

Hasil perhitungan data 2019

Dengan derajat kebebasan 3 , nilai $\chi^{2}$ tabel pada taraf signifikan $1 \%$ adalah sebesar 11,34. Dan seperti terlihat pada tabel 4.2 nilai $\chi^{2}$ hitung kelas eksperimen sebesar 1,00 menunjukan data hasil pretest kelas eksperimen berdistribusi normal. Begitu juga nilai $\chi^{2}{ }_{\text {hitung }}$ kelas kontrol sebesar 2,79 menunjukan data hasil pretest kelas kontrol juga berdistribusi normal. Untuk perhitungan dapat dilihat pada lampiran halaman 133 dan 137.

Karena keduanya berdistribusi normal, maka selanjutnya dilkukan uji homogenitas kedua varians. Uji homogenitas dua varians dihitung dengan menggunakan uji $\mathrm{F}$. Dari hasil perhitungan diperoleh:

Tabel 3

Uji Homogenitas Kedua Varians

\begin{tabular}{|c|c|c|c|c|}
\hline Kelas & Simp. Baku & Varians & $F_{\text {hitung }}$ & $F_{\text {tabel }}$ \\
\hline Eksperimen & 13 & 158,14 & \multirow{2}{*}{0,57} & 2,86 \\
\hline Kontrol & 22 & 481,44 & & \\
\hline
\end{tabular}


Dengan $F_{\text {hitng }}=0,57$ dan $F_{\text {tabel }}$ hasil perhitungan alpha 0,01 yang dicari dengan interpolasi $\mathrm{F}_{\text {tabel }}=2,86$ berarti $\mathrm{F}_{\text {hitung }}<\mathrm{F}_{\text {tabel }}$, maka dapat disimpulkan bahwa kedua varians homogen.

Karena kedua varians homogen maka selanjutnya dilakkukan uji kesamaan dua ratarata. Dari hasil perhitungan uji normalitas dan uji homogenitas diketahui bahwa data hasil pretest kelas eksperimen dan kelas kontrol berdistribusi normal dan kedua varians homogen, maka selanjutnya dilakukan uji hipotesis dengan menggunakan uji t.

\section{Tabel 4}

Uji Hipotesis

\begin{tabular}{|c|c|c|c|c|c|}
\hline Kelas & $\mathrm{N}$ & $\mathrm{N}\left(\mathrm{n}_{1}+\mathrm{n}_{2}\right)$ & $\mathrm{t}_{\text {hitung }}$ & $\mathrm{t}_{\text {tabel }}$ & Kesimpulan \\
\hline Eksperimen & 22 & 42 & $-3,02$ & 2,70 & $\begin{array}{l}\text { Tidak Ada } \\
\text { perbedaan }\end{array}$ \\
\hline Kontrol & 22 & & & & \\
\hline
\end{tabular}

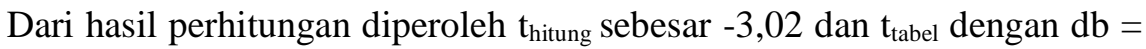
42, $\alpha=0,01$ sebesar 2,70 . Berdasarkan Kaidah keputusan:

1. Jika $\mathrm{t}_{\text {hitung }}>\mathrm{t}_{\text {tabel }}$, maka $\mathrm{H}_{\mathrm{a}}$ diterima

\section{Jika $\mathrm{t}_{\text {tabel }}>\mathrm{t}_{\text {hitung }}$ maka $\mathrm{H}_{\mathrm{O}}$ diterima}

maka $t_{\text {hitung }}$ berada di daerah penerimaan $\mathrm{H}_{\mathrm{o}}$, Sehingga dapat disimpulkan bawa kemampuan awal siswa kelas eksperimen dan kelas kontrol sama.

Analisis data hasil posttest pada kelas eksperimen dan kelas kontrol bertujuan untuk mengetahui kemampuan siswa setelah diberikan materi pelajaran dan pembelajaran. Setelah semua data yang diperlukan terkumpul, maka selanjutnya dilakukan pengolahan data berdasarkan langkah-langkah yang telah diuraikan sebelumnya.

Tabel 5

Nilai Rata-Rata dan Simpangan Baku

\begin{tabular}{|c|c|c|c|}
\hline Kelas & Jumlah Siswa & Rata-rata & Simpangan baku \\
\hline Eksperimen & 22 & 82 & 27 \\
\hline Kontrol & 22 & 77 & 32 \\
\hline
\end{tabular}

Berdasarkan tabel 5 terlihat bahwa rata-rata skor kelas eksperimen lebih besar dari pada kelas kontrol. Hal ini menunjukan bahwa setelah diberikan pembelajaran kemampuan rata-rata kelas eksperimen lebih baik dari pada kelas kontrol. 
Berdasarkan hasil penelitian yang telah diuraikan, dapat diketahui bahwa pelaksanaan pembelajaran dengan menerapkan media gambar animasi berjalan dengan baik. Dimana dalam pelaksanaannya menggunakan dua kelas yaitu eksperimen kelas IV Ilyas dengan menerapkan media gambar animasi dan kelas kontrol IV Sulaiman menggunakan metode ceramah. Keduanya diberikan prestest untuk mengetahui keadaan awal siswa, dan dapat disimpulkan bahwa kemampuan awal siswa sebelum diberikan perlakuan relatif sama dan tidak jauh berbeda.

Tetapi setelah diberikan perlakuan dengan menerapkan media gambar animasi siswa kelas eksperimen mengalami peningkatan yang cukup pesat dibandingkan dengan siswa kelas kontrol yang hanya menerapakan metode ceramah, hal ini dapat dilihat dari perolehan nilai rata rata hasil posttest yaitu kelas ekperimen yang berjumlah 22 siswa memiliki nilai rata rata 82 sedangkan nilai rata rata kelas kontrol yang berjumlah 22 siswa memiliki nilai rata rata 77. Hal tersebut menunjukkan adanya peningkatan hasil belajar siswa sebelum dan sesudah media gambar animasi diterapkan.

Berdasarkan hasil pengolahan data di atas, sebaran data kelas eksperimen dengan sampel yang berjumlah 22 siswa berdistribusi normal. Hal ini dapat dibuktikan dari uji normalitas data terhadap data kelas eksperimen yang menghasilkan nilai $\mathrm{X}^{2}$ hitung $(6,41)<X^{2}$ tabel $(11,34)$, maka sebaran data kelas eksperimen berdistribusi normal.

Selanjutnya uji normalitas data yang dilakukan pada kelas kontrol dengan sampel berjumlah 22 siswa. Dari pengujian normalitas tersebut, diperoleh nilai $\mathrm{X}^{2}$ hitung $(6,48)<\mathrm{X}^{2}$ tabel $(11,34)$, maka sebaran data kelas kontrol juga berdistribusi normal.

Setelah diketahui bahwa data kelas eksperimen dan kelas kontrol masing-masing memiliki data yang berdistribusi normal, maka langkah selanjutnya adalah pengujian homogenitas dua varians. Dari pengujian tersebut diperoleh nilai $F_{\text {hitung }}=0.85<$ nilai $\mathrm{F}_{\text {tabel }}=2,86$, maka kedua varians tersebut dinyatakan homogen.

Pada tahap uji normalitas dan uji homogenitas diketahui sebaran data masing masing kelas berdistribusi normal dan memiliki variansi yang homogen. Berdasarkan hal tersebut maka pengujian hipotesis dilakukan dengan menggunakan statistika parametric uji t dengan kiteria pengujian sebagai berikut :

a. Jika t-hitung < t-tabel, maka $\mathrm{H}_{0}$ diterima, artinya hasil belajar siswa pada mata pelajaran SKI yang diberi perlakuan dengan menerapkan media gambar animasi sama dengan hasil belajar siswa yang diajarkan dengan menggunakan metode ceramah.

b. Jika t-hitung > t-tabel maka $\mathrm{H}_{1}$ diterima, artinya hasil belajar siswa pada mata pelajaran SKI yang diajarkan dengan menerapkan media gambar animasi lebih baik daripada hasil belajar siswa yang diajarkan dengan menggunakan metode ceramah. 
Setelah dilakukan uji t dengan satu pihak dengan $\mathrm{db}=42, \alpha=0,01 \%$ diperoleh nilai $t_{\text {hitung }}$ sebesar 3,24 dan $t_{\text {tabel }}$ sebesar 2,70, jika dibandingkan $\mathrm{T}_{\text {hitung }}$ dengan $\mathrm{T}_{\text {tabel}}$, maka $\mathrm{T}_{\text {hitung }}$ lebih besar daripada $\mathrm{T}_{\text {tabel }}\left(\mathrm{T}_{\text {hitung }}>\mathrm{T}_{\text {tabel }}\right)$. Dengan demikian hipotesis $\left(\mathrm{H}_{1}\right)$ diterima, yang artinya hasil belajar siswa pada mata pelajaran SKI dengan menerapkan media gambar animasi lebih baik daripada hasil belajar siswa yang menggunakan metode ceramah. Sehingga penelitian ini dapat membuktikan bahwa pembelajaran dengan media gambar animasi dapat meningkatkan hasil belajar siswa.

Di kuatkan dalam gain hasil belajar dari kedua kelas memiliki peningkatan. Hasil pretest kelas eksperimen memiliki nilai rata-rata 59, setelah di terapkan media gambar animasi, nilai rata-rata postest menjadi 82, peningkatannya sebesar $23 \%$. Dan dikelas kontrol hasil belajar siswa juga memiliki peningkatan. Hasil pretest kelas kontrol memiliki nilai rata-rata 63, setelah menggunakan metode ceramah, nilai rata-rata postest menjadi 77 , peningkatannya sebesar $14 \%$. Jadi, bisa kita lihat kelas eksperimen memiliki nilai rata-rata yang lebih rendah dari kelas kontrol.

Bisa kita lihat dalam grafik dibawah ini yang menunjukkan adanya perubahan dari Pretest ke Posttest, sebagai berikut :

Gambar 6.1

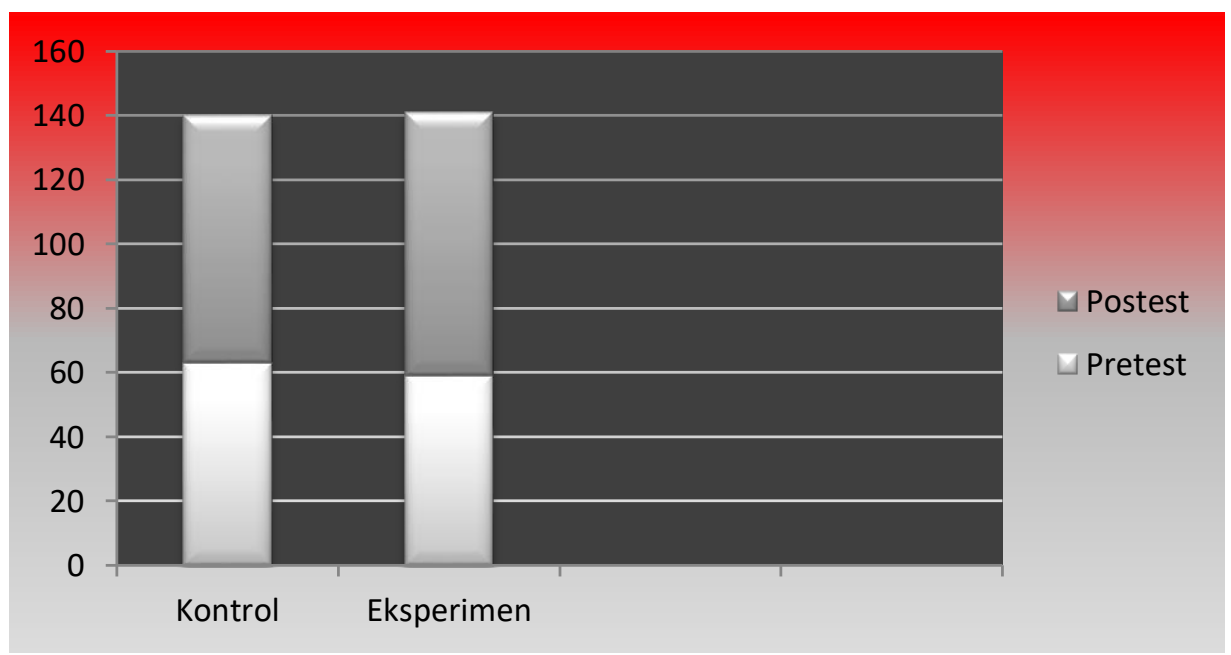

Oleh karena itu, peneliti menerapkan media gambar animasi untuk meningkatkan nilai yang di bawah KKM (hasil belajar). Adapun hasilnya, bisa kita lihat bahwa hasil belajar siswa setelah di terapkannya media gambar animasi di kelas eksperimen lebih meningkat. Sedangkan kelas kontrol memiliki nilai rata-rata yang relatif sama dengan kelas eksperimen tapi tidak menggunakan media gambar animasi melainkan metode ceramah. Keduanya memiliki peningkatan yang 
signifikan tetapi perbedaannya kelas eksperimen yang menggunakan media gambar animasi lebih efektif dan lebih baik di bandingkan kelas yang menggunakan metode ceramah. Maka, dapat di simpulkan bahwa hasil belajar siswa kelas kontrol tidak sebaik kelas eksperimen yang menggunakan media gambar animasi. Secara keseluruhan peningkatan hasil belajar siswa dengan menggunakan media gambar animasi peningkatannya mencapai $56 \%$.

Menurut (Appang, Sugiarti, \& Salempa, 2017) terbukti media animasi ini memang mampu menarik serta bermanfaat bagi proses pembelajaran karena menggabungkan grafik dan suara yang tidak membosankan dan mampu membuat siswa lebih bersemangat dalam proses belajar mengajar. Media animasi ini mampu meningkatkan hasil belajar siswa.

Menurut Suharsimi Arikunto (2010:274) dalam sebuah hasil belajar kita menginginkan hasil yang bagus, karena memang dari penelitian saya hasil belajar siswa di kelas eksperimen dan kelas kontrol sama-sama meningkat. Karena media yang digunakan memang tepat.

Menurut (Purwanto, 2016) perubahan prilaku juga yang menentukan hasil belajar seseorang, siswa lebih menjadi antusias ketika belajar tentang SKI, karena medianya sudah berbeda dari sebelumnya dan lebih bisa menerima dan menyukai bahwa pelajaran SKI itu tidak selamaya membosankan.

\section{Kesimpulan dan Saran}

Kesimpulan dalam penelitian ini adalah adanya perbedaan hasil belajar sejarah kebudayaan Islam antara siswa yang diberi tindakan media animasi dan siswa tanpa dikenai penggunaan media animasi. Berdasarkan rata-rata jelas sekali terlihat perbedaanya, ini menunjukkan media animasi efektif dalam meningkatkan hasil belajar SKI.

Dengan penelitian ini menjadi salah satu studi lanjutan yang relevan untuk pengembangan, peningkatan, dan pembahuruan media pembelajaran. Dengan rasa kesadaran yang tinggi bahwa media pembelajaran berorientasi untuk pertimbangan konseptual dan kontekstual, serta budaya yang berkembang di dunia pendidikan terlebih menghadapi era revolusi industry 4.0. Selain itu, media ini merupakan sebuah karya di bidang pendidikan yang bukan hanya pada pembelajaran Sejarah Kebudayaan Islam namun bisa dikembangkan pada mata pelajaran lain khususnya di sekolah dasar Islam Terpadu.

\section{Daftar Pustaka}

Amirul, F. H. (2017). Pengertian Media Gambar. Dipetik 2 9, 2020, dari http://fatkhan.web.id/pengertian-media-gambar 
Appang, R. A., Sugiarti, \& Salempa, P. (2017). Pengaruh Penggunaan Media Animasi melalui Model Pembelajaran Inkuiri Terbimbing Terhadap Motivasi dan Hasil Belajar Siswa Kelas VII SMPN 30 Makassar (Studi pada Materi Pokok Karakteristik Zat). Jurnal Chemica, 18(2), 80 - 89.

Purwanto. (2016). Evaluasi Hasil Belajar. Yogyakarta: Pustaka Pelajar.

Rumainur, R., \& Razak, A. (2020). Efektivitas Pembelajaran Sejarah Kebudayaan Islam dengan Menggunakan Multimedia Autoplay di Kelas XI Madrasah Aliyah Kota Samarinda. SYAMIL: Jurnal Pendidikan Agama Islam (Journal of Islamic Education), 8(1), 1-14.

Sari, N. W., \& Samawi, A. (2014). Pengaruh penggunaan media animasi terhadap hasil belajar IPA siswa slow learner. Jurnal Penelitian dan Pengembangan Pendidikan Luar Biasa, 1(2), 140-144 